\title{
BACTERIA LOADS OF PUBLIC TRANSPORT IN THE TAMALE METROPOLIS, GHANA
}

\author{
Abdulai, M., Abubakari, Z. I., Cobinna, S. J., *Oduro D. \\ Department of Ecotourism and Environmental Management, University for Development Studies, Tamale, Ghana. \\ *Corresponding Author's Email: debbyoduro96@gmail.com
}

\begin{abstract}
Investigations for pathogenic microbes on surfaces of objects have been attaining significant consideration from public health researchers for some time now. This is especially because of the risk of the spread of diseases of public health concern. Consequently, this study was conducted to provide information on bacterial contamination levels in taxis and motorised tricycles operating from the Tamale Main Taxi Rank. Forty samples from taxis and tricycle seats were collected and analysed. All samples contained Escherichia coli, Salmonella spp, and Shigella spp. Taxis contained significantly $(p<0.006)$ more bacteria than tricycles (mean bacterial loads of $20.35 \times 10^{6}$ $\mathrm{CFU} / \mathrm{ml}$ and $2.80 \times 10^{6} \mathrm{CFU} / \mathrm{ml}$ respectively). Also, considering the materials with which the vehicle seats were made vinyl contained more bacteria $\left(14.06 \times 10^{6} \mathrm{CFU} / \mathrm{ml}\right)$ than cloth $\left(10.98 \times 10^{6} \mathrm{CFU} / \mathrm{ml}\right)$ and polythene $\left(1.12 \times 10^{6} \mathrm{CFU} / \mathrm{ml}\right)$. Using the Kruskal-Wallis test for analysing bacteria loads across material types, it was found that there was a significant difference $(p<0.026)$ between bacteria numbers and material types. The bacteria isolates showed resistance to the antibiotics, ampicillin (10 $\mu \mathrm{g})$, Ceftazidime (30 $\mu \mathrm{g})$, Cefotaxime (30 $\mu \mathrm{g})$, and Ciprofloxacin $(5 \mu \mathrm{g})$. Taxis and tricycles in some parts of the Metropolis operate under poor hygienic conditions. It is recommended that routine cleaning and disinfection of vehicles as well as the practice of personal hygiene be highly encouraged to keep a safer and healthier urban population and environment.
\end{abstract}

\section{Keywords: Escherichia coli, Pathogenic, Salmonella spp, Shigella spp}

\section{Introduction}

Microorganisms are living things that are very tiny and can only be seen with the help of microscopes. Microorganism are the leading organisms on earth when it comes to numbers and range of circulation. Microorganisms are ubiquitous (found in soil, water, and air) and live either spontaneously or as parasites in the environment (Sleigh \& Timbury, 1998). Our hands usually contain microorganisms contracted from the environment (Lindberg et al., 2004; Oranusi et al., 2013). In some instances, microorganisms are found in fomites where they pose health hazards (Pittet et al., 1999). Public places including restaurants, day-care centres, public transport, playgrounds, education centres, and many others can aid the spread of microorganisms to several people (Kassem et al., 2007). This becomes a serious problem when pathogens become resistant to antibiotics (Yeh et al., 2011).

Contact with surfaces contaminated with infectious microorganisms is a way to spread diseases such as cold, flu, diarrhoea, and other infections (Boone \& Gerba, 2007). Public transport systems host a huge number of passengers and enable a persistent stream of person to person and humans to build environment microbial transfer (Hsu et al., 2016). This interaction has pinched great responsiveness from public-health researchers as pathogenic microorganisms have gotten an enhanced way of 
multiplication which is quicker and extensive in quantity than before (Otter \& French, 2009).

Several studies have been conducted concentrating on the occurrence and profusion of infectious microorganisms from hand touch surfaces. These include contamination from surfaces of buses, mobile phones, trains, Automated Teller Machines (ATM) booths, hand knobs, hospitals, and shopping carts. Bacterial isolated from these surfaces include Escherichia coli, Mycobacterium tuberculosis, Vibrio cholerae, Salmonella spp, multidrug-resistant Staphylococcus aureus (MRSA), and Shigella spp (Chowdhury et al., 2016).

People have access to taxis and motorised tricycles ("yellow yellow") regularly for their day to day movements within the township of Tamale. Given that the seats of these taxi cabs and motorised tricycles are not often sterilised, the possibility for the transfer of pathogenic microbes is high. Therefore, this research work investigated the presence and levels of E. coli, Salmonella spp, and Shigella spp on the seats of taxi cabs and motorised tricycles. The sensitivities of the bacteria isolate to selected antibiotics were also tested.

\section{Materials and Methods Collection of Sample}

This study was carried out on public transport (Taxis and Motorised tricycles) operating in the Tamale taxi rank from November 2017 to June 2018. Sampling was carried out between the hours of 8:00 am and 10:00 am when the usage of these vehicles was high. Sterile swabs were used to wipe surfaces of seats of taxis and tricycles, then capped, stored in iced boxes and transported to the laboratory for analysis. A total of 40 swab samples were collected, 20 from taxis, and 20 from motorised tricycles on a random basis.

\section{Microbial Analysis}

Sterilisation of Glass Ware and Equipment, and List of Media Used

Laboratory benches and tables were sterilised with $70 \%$ isopropyl alcohol. Autoclaving at $121^{\circ} \mathrm{C}$ for 15 minutes was used to sterilise glassware. Pipettes used in this work were also sterilised in an oven ( $\mathrm{J}$. P- Selecta, Spain) at $250{ }^{\circ} \mathrm{C}$ for 2 hours whilst inoculating loops were sterilised by flaming over a gas flame. The media used were nutrient agar, xylose-lysine-deoxycholate (XLD), and MullerHinton agar.

\section{Sample Preparation}

Swabs were dipped in $9 \mathrm{ml}(0.1 \%)$ sterile peptone water for 5 minutes whilst constantly shaking for proper mixing of samples (Bodur \& CagriMehmetoglu, 2012). Ten-fold serial dilution of samples was prepared at four levels.

\section{Inoculation, Incubation, and Enumeration of Total} Viable Bacteria

$0.1 \mathrm{ml}$ each of $10^{0}, 10^{-1}, 10^{-2}, 10^{-3}$, and $10^{-4}$ dilutions were taken aseptically under a laminar flow hood and inoculated on a solidified Nutrient agar. The inoculated plates were inverted and incubated at 37 ${ }^{\circ} \mathrm{C}$ for 24 hrs. Total viable bacteria were enumerated based on a colony-forming unit per millimetres (CFU/ml).

\section{Isolation and Identification of Enteric Bacteria}

Sterile inoculating loops were used to pick colonies and sub-cultured onto Xylose Lysine Dextrose (XLD) agar. The physical and biochemical characteristics of the sub-cultured colonies were examined to confirm their identity. Xylose Lysine Dextrose (XLD) Agar is recommendable for the isolation of Enterobacteriaceae (Wehr et al., 2004). XLD Agar displays better selectivity as matched to other plating media like Salmonella-Shigella Agar, EMB Agar, and Bismuth Sulphite Agar (Wehr et al., 2004). With this agar, the growth of pink-red colonies with black centres was identified as Salmonella spp whilst the growth of pink-red colonies with no black centres identified as Shigella spp and yellow colonies depicted as E. coli. 


\section{Antibiotic Susceptibility Test}

Antibiotic susceptibility test was performed according to the Kirby Bauer method (Yeh et al., 2011). The resistance of the bacterial isolates to antibiotics was measured using standardised antibiotic discs of Clindamycin $(2 \mu \mathrm{g})$, Ampicillin $(10 \mu \mathrm{g})$, Erythromycin $(5 \mu \mathrm{g})$, Metronidazole $(8 \mu \mathrm{g})$, Cefotaxime $(30 \mu \mathrm{g})$, Chloramphenicol $(30 \mu \mathrm{g})$, Ciprofloxacin $(5 \mu \mathrm{g})$, Ceftazidime $(30 \mu \mathrm{g})$, Oxacillin $(1 \mu \mathrm{g})$ and Tetracycline $(10 \mu \mathrm{g})$.

Each isolate was subcultured and the bacterial suspension was set in nutrient broth for antibiotic susceptibility tests. The turbidity of the culture was accustomed to the McFarland standard 0.5 (Chowdhury et al., 2016).

A sterilised cotton swab was immersed in the prepared culture and streaked on the surface of the Muller-Hinton agar medium to get even inoculums. The antibiotic discs were then positioned on the surface of the inoculated plates by using sterile forceps and kept at $4{ }^{\circ} \mathrm{C}$ for 30 minutes to diffuse antibiotic in the media (Yeh et al., 2011). The plates were incubated at $37{ }^{\circ} \mathrm{C}$ for 24 hours and the diameter of the clear zone of inhibition was measured and defined according to the standards table of the European Committee on Antimicrobial Sensitivity Testing (2018).

\section{Results}

\section{Bacteria Estimates from Vehicles}

The bacteria load from vehicles (taxis and tricycles) ranged between $0.12 \times 10^{6}$ to $86 \times 10^{6} \mathrm{CFU} / \mathrm{ml}$. Among the taxis, the minimum bacteria count was $0.12 \times 10^{6}$, and the maximum, $86 \times 10^{6} \mathrm{CFU} / \mathrm{ml}$ (Table 1). For tricycles, the minimum was $0.47 \times 10^{6}$, and the maximum, $13 \times 10^{6} \mathrm{CFU} / \mathrm{ml}$. Mann-Whitney $\mathrm{U}$ test showed $p$ value of 0.006 .

Table 1: Bacteria loads categorised according to vehicle type and seat material

\begin{tabular}{lllll}
\hline & $\begin{array}{l}\text { Minimum } \\
(\mathrm{CFU} / \mathrm{ml})\end{array}$ & $\begin{array}{l}\text { Maximum } \\
\text { (CFU/ml) }\end{array}$ & Mean $(\mathrm{CFU} / \mathrm{ml})$ & Standard deviation \\
\hline Taxi & $0.12 \times 10^{6}$ & $86 \times 10^{6}$ & $20.35 \times 10^{6}$ & $25.75 \times 10^{6}$ \\
Tricycle & $0.47 \times 10^{6}$ & $13 \times 10^{6}$ & $2.80 \times 10^{6}$ & $3.30 \times 10^{6}$ \\
Cloth & $0.6 \times 10^{6}$ & $41.3 \times 10^{6}$ & $10.98 \times 10^{6}$ & $19.02 \times 10^{6}$ \\
Vinyl & $0.53 \times 10^{6}$ & $3.1 \times 10^{6}$ & $14.06 \times 10^{6}$ & $23.09 \times 10^{6}$ \\
Polythene & $0.12 \times 10^{6}$ & $86 \times 10^{6}$ & $1.12 \times 10^{6}$ & $0.97 \times 10^{6}$ \\
\hline
\end{tabular}

Source: Field survey (2018)

\section{Distribution of Bacteria Isolates between Vehicle Types}

Taxis recorded the highest levels of $E$. coli contamination with as much as 15 taxis recording positive $E$. coli growth whilst 12 samples from motorised tricycles had E. coli growth (Table 2). In the case of Salmonella, 10 taxis had samples showing a growth of Salmonella spp whilst only 8 samples from motorised tricycles showed growth of Salmonella spp. Shigella spp was detected in 13 taxis whilst 10 samples from motorised tricycles showed growth of Shigella spp.

Table 2: Isolated Bacteria from Vehicles

\begin{tabular}{lllllll}
\hline & \multicolumn{2}{c}{ Taxis } & \multicolumn{3}{c}{ Motorised tricycles } \\
& E. coli & Salmonella spp & Shigella spp & E. coli & Salmonella spp & Shigella spp \\
\hline Present & 15 & 10 & 13 & 12 & 8 & 10 \\
Absent & 5 & 10 & 7 & 8 & 12 & 10 \\
Total & 20 & 20 & 20 & 20 & 20 & 20 \\
\hline
\end{tabular}

Source: Field survey (2018) 


\section{Bacteria Loads of Seat Materials}

Bacteria loads of vehicle seats made from cloth ranged from $0.60 \times 10^{6}$ to $41.30 \times 10^{6} \mathrm{CFU} / \mathrm{ml}$, whilst that of polythene ranged from $0.53 \times 10^{6}$ to $3.10 \times 10^{6} \mathrm{CFU} / \mathrm{ml}$ and vinyl $0.12 \times 10^{6}$ to $86 \times 10^{6} \mathrm{CFU} / \mathrm{ml}$ (Table 1). There was a significant difference in bacteria numbers between the material types $(p=0.026)$.

Five cases of $E$. coli occurrence were reported from seats made with cloth, 20 from seats made with vinyl, and 2 from seats covered with polythene (Table 3). Out of the 18 cases of Salmonella spp occurrence, 4 were from seats made with cloth, 13 from seats made with vinyl, and 1 from seat covered with polythene. In the case of Shigella spp, 6 were from seats made with polythene, 14 from seats made from vinyl, and 3 from seats covered with cloth.

Table 3: Bacteria Isolates across Seat Materials

\begin{tabular}{|c|c|c|c|c|c|c|}
\hline \multirow{3}{*}{ Bacteria } & \multicolumn{6}{|c|}{ Materials } \\
\hline & Vinyl & & Cloth & & & iene \\
\hline & Present & Absent & Present & Absent & Present & Absent \\
\hline E. coli & 20 & 7 & 5 & 2 & 2 & 4 \\
\hline Salmonella spp & 13 & 14 & 4 & 3 & 1 & 5 \\
\hline Shigella spp & 14 & 13 & 3 & 3 & 6 & 1 \\
\hline
\end{tabular}

Source: Field survey (2018)

A correlation analysis showed that $E$. coli correlated positively and significantly with Salmonella $\operatorname{spp}(\mathrm{p}<0.008)$ whilst the type of vehicle correlated positively and significantly with seat material type at $p=0.000$. Bacteria load (CFU/ml) correlated negatively with the vehicle type and seat material type (Table 4).

\section{Antibiotics Sensitivity Pattern}

Using the Spearman Correlation Matrix, responses of microbes to antibiotics discs on Muller Hinton agar are presented in the table below. 
Table 4: Responses of microbes to antibiotics discs on Muller Hinton agar

The bacteria isolates showed resistance to the antibiotics, ampicillin $(10 \mu \mathrm{g})$, Ceftazidime (30 $\mu \mathrm{g})$, Cefotaxime $(30 \mu \mathrm{g})$, and Ciprofloxacin (5 $\mu \mathrm{g})$ (Table 5).

\begin{tabular}{|c|c|c|c|c|c|c|c|}
\hline & & $\begin{array}{l}\text { Type of } \\
\text { vehicle }\end{array}$ & Material & $\begin{array}{l}\text { CFU/ml } \\
\left(* 10^{\wedge} 6\right)\end{array}$ & E. coli & Salmonella & Shigella \\
\hline \multirow{3}{*}{$\begin{array}{l}\text { Type of } \\
\text { vehicle }\end{array}$} & $\begin{array}{l}\text { Correlation } \\
\text { Coefficient }\end{array}$ & 1.000 & $.571^{* *}$ & $-.438^{* *}$ & -.160 & -.101 & -.152 \\
\hline & Sig. (2-tailed) & & .000 & .005 & .324 & .537 & .350 \\
\hline & $\mathrm{N}$ & & 40 & 40 & 40 & 40 & 40 \\
\hline \multirow{3}{*}{ Material } & $\begin{array}{l}\text { Correlation } \\
\text { Coefficient }\end{array}$ & & 1.00 & $-.392^{*}$ & -.215 & -.224 & -.217 \\
\hline & Sig. (2-tailed) & & $\cdot$ & .012 & .182 & .165 & .178 \\
\hline & $\mathrm{N}$ & & & 40 & 40 & 40 & 40 \\
\hline \multirow{3}{*}{$\begin{array}{l}\text { cfu/ml } \\
\left(* 10^{\wedge} 6\right)\end{array}$} & $\begin{array}{l}\text { Correlation } \\
\text { Coefficient }\end{array}$ & & & 1.000 & $.349^{*}$ & .259 & .046 \\
\hline & Sig. (2-tailed) & & & . & .027 & . 106 & .778 \\
\hline & $\mathrm{N}$ & & & & 40 & 40 & 40 \\
\hline \multirow{3}{*}{ E. coli } & $\begin{array}{l}\text { Correlation } \\
\text { Coefficient }\end{array}$ & & & & 1.000 & $.413^{* *}$ & .267 \\
\hline & Sig. (2-tailed) & & & & & .008 & . 096 \\
\hline & $\mathrm{N}$ & & & & & 40 & 40 \\
\hline \multirow{3}{*}{ Salmonella } & $\begin{array}{l}\text { Correlation } \\
\text { Coefficient }\end{array}$ & & & & & 1.000 & .168 \\
\hline & Sig. (2-tailed) & & & & & . & .301 \\
\hline & $\mathrm{N}$ & & & & & & 40 \\
\hline \multirow{3}{*}{ Shigella } & $\begin{array}{l}\text { Correlation } \\
\text { Coefficient }\end{array}$ & & & & & & 1.000 \\
\hline & Sig. (2-tailed) & & & & & & $\cdot$ \\
\hline & $\mathrm{N}$ & & & & & & \\
\hline
\end{tabular}

**. Correlation is significant at the 0.01 level (2-tailed).

*. Correlation is significant at the 0.05 level (2-tailed). 
Table 5: Bacteria Responses to Antibiotics

\begin{tabular}{llllllllll}
\hline Antibiotics & \multicolumn{3}{l}{ E. coli } & \multicolumn{3}{c}{ Salmonella spp } & \multicolumn{3}{c}{ Shigella spp } \\
& $S$ & $I$ & $R$ & $S$ & $I$ & $R$ & $S$ & $I$ & $R$ \\
\hline Ampicillin $(10 \mu \mathrm{g})$, & 0 & 0 & 27 & 0 & 0 & 18 & 0 & 0 & 23 \\
Erythromycin $(5 \mu \mathrm{g})$, & - & - & - & - & - & - & - & - & - \\
Metronidazole $(8 \mu \mathrm{g})$, & - & - & - & - & - & - & - & - & - \\
Clindamycin $(2 \mu \mathrm{g})$, & - & - & - & - & - & - & - & - & - \\
Tetracycline $(10 \mu \mathrm{g})$. & - & - & - & - & - & - & - & - & - \\
Oxacillin $(1 \mu \mathrm{g})$, & - & - & - & - & - & - & - & - & - \\
Ceftazidime $(30 \mu \mathrm{g})$, & 7 & 0 & 20 & 3 & 1 & 14 & 10 & 3 & 10 \\
Ciprofloxacin $(5 \mu \mathrm{g})$, & 24 & 1 & 2 & 16 & 0 & 2 & 17 & 5 & 1 \\
Chloramphenicol $(30 \mu \mathrm{g})$, & 27 & 0 & 0 & 17 & 1 & 0 & 23 & 0 & 0 \\
Cefotaxime $(30 \mu \mathrm{g})$, & 13 & 8 & 6 & 9 & 3 & 6 & 16 & 3 & 4 \\
\hline
\end{tabular}

Where '-'is no breakpoint; ' $\mathrm{S}$ ' susceptible; $\mathrm{R}$ is resistance and I is intermediate

\section{Discussion}

The seats of the vehicles sampled for this study were contaminated with bacteria. Several studies have shown bacteria occurrence on surfaces of buses, trains, mobile phones, doorknobs, computer keyboards though these surfaces are non-nourishing items for microbial growth (Pittet et al., 1999). Various factors explain the occurrence of bacteria on these surfaces. For instance, the profusion of bacteria on seats can be attributed to the irregular cleaning of vehicles, poor public sanitation practice, and lack of awareness of bacteria spread among public transport operators. These probable causes of bacterial presence on the vehicles were confirmed with an interview conducted during the sample collection where most drivers indicated they only clean their vehicles when they were very dirty. The higher bacteria numbers on taxis were associated with the fact that most of the taxis were relatively older and also had more cases of infrequent cleaning. This realization could also be due to the higher patronage of taxis as compared to the tricycles.

Concerning the materials used to make the seats of vehicles sampled, the following associations were made about their bacteria loads. The lower bacteria load of seats covered with polythene was associated with the fact that polythene can heat up to higher temperatures (especially during sunshine) providing unsuitable conditions for bacteria proliferation Also, the smooth nature of polythene presents comparatively less suitable surfaces for microbial attachments. Besides, the low numbers could be due to the relative ease with which one can clean and disinfect polythene made seats as compared to vinyl and cloth.

The presence of larger numbers of bacteria in vinyl and cloth-based seats was attributed to several factors. Principally these materials provide good surfaces for microbial attachments because of their coarse nature. They also retain some moisture and comparatively moderate heat which are conducive for microbial proliferation. Their cleaning and disinfection are also relatively difficult. The presence of E. coli is a hint of recent sewage or animal waste contamination (Meng \& Doyle 2002). Thus, it was possible that some passengers who might have come in contact with faecal matter transferred these bacteria onto vehicle seats. The contamination could also be from water used to clean the seats of sampled vehicles. The occurrence of $E$. coli on surfaces has been reported by other studies. For instance, in a research conducted by Meng \& Doyle (2002), E. coli was isolated in all the environmental surfaces studied except refrigerated water taps in the streets and surfaces of cans of 
carbonated drinks. The presence and spread of pathogenic strains of $E$. coli are worrying. The enteropathogenic strain (for example $E$. coli 0157:H7) causes gastrointestinal illness in healthy individuals (Ray, 2004). In Ghana, diarrhoea caused by $E$. coli has been identified as one of the major prompts of hospital turnout and $16 \%$ of mortality in youngsters below five years in Africa (Bryce et al., 2005).

Salmonella spp occurrence depicted a greater human health risk, especially for food poisoning cases. The bacterium is mostly associated with crosscontamination of food products especially from eggs and egg products. Salmonella spp are mostly assumed to have only a human or primate host (Winfield \& Groisman, 2003). Consequently, its presence on vehicle seats was believed to come from a human host. The presence and spread of Salmonella spp are generally of public health concern especially because of the disease condition (Typhoid fever) they present. Shigella spp is known to cause an acute invasive enteric infection known as Shigellosis and it is recognised as a major public health problem. The presence of Shigella spp on sampled vehicles might be due to poor hygienic practices of passengers and drivers.

The existence of a positive and significant correlation between E. coli and Salmonella spp implied that E. coli and Salmonella spp possibly occurred together but this was not enough evidence to conclude that the presence of $E$. coli could indicate the presence of Salmonella spp. It also could mean that these bacteria originated from the same source. Notwithstanding these, it is believed both bacteria can be parasites to animal hosts (Winfield \& Groisman, 2003). Also, the observation of a good and significant relationship between type of vehicle and seat material implied that, one could tell a type of vehicle at the Tamale taxi rank just by its seat material. That is vinyl and cloth are to taxis, whilst polythene is to tricycles. However, the negative and significant relationship between bacteria load and type of vehicle seat-material suggests that increases in bacteria numbers did not depend on the most used seat material type. Consequently, other factors including poor hygiene and poor vehicle maintenance could account for increments in bacteria loads across the vehicle types.

The antimicrobial activities of isolated bacteria in this research is not an isolated case. Earlier research works have shown that, E. coli, Salmonella spp, and Shigella spp exhibit resistance to ampicillin $(10 \mu \mathrm{g})$ (Chowdhury et al., 2016). Some other findings have shown that some Salmonella spp are resistant to tetracycline and ampicillin (Bouchrif et al., 2009). Antibiotic activities reported here were associated with the ability of bacteria to develop effective defence mechanisms against the fatal effects of antibiotics. It is proposed that the use of subtherapeutic doses of antimicrobials in animal feedstuff has led to an increase in resistant strains of pathogenic bacteria (Fluckey et al., 2007). Approximately $50 \%$ of antimicrobial drug use occurs under animal rearing (Fluckey et al., 2007). A common opinion is that sub-therapeutic doses administered over a long period have made it possible for most bacteria to develop resistance. Hence, the more a particular antibiotic is abused or used, the more likely that bacteria will develop resistance to it.

\section{Conclusion}

This study revealed that public transport in the Tamale Metropolis could be a means of transmission of pathogenic bacteria. Thus, taxis especially should be used with care to avoid the possible contraction of diseases. Routine cleaning and disinfection of vehicles alongside the encouragement of the practice of personal hygiene is necessary to keep a safer and healthier urban population and environment.

\section{References}

Bodur, T., \& Cagri-Mehmetoglu, A. (2012). Removal of Listeria monocytogenes, Staphylococcus aureus, and Escherichia coli O157:H7 biofilms on stainless steel using scallop shell powder. Food Control, 25; 1-9.

Bouchrif, B., Paglietti, B., Murgia, M., Piana, A., Cohen, N., Ennaji, M. M., \& Timinouni, M. 
(2009). Prevalence and antibiotic-resistance of Salmonella isolated from food in Morocco. The Journal of Infection in Developing Countries, 3(01); 035-040.

Boone, S. A., \& Gerba, C. P. (2007). Significance of fomites in the spread of respiratory and enteric viral disease. Appl. Environ. Microbiology. 73(6); 1687-1696.

Bryce, J., Boschi-Pinto, C., Shibuya, K., Black, R. E., \& WHO Child Health Epidemiology Reference Group. (2005). WHO estimates of the causes of death in children. The Lancet, 365(9465): 1147-1152.

Chowdhury, T., Mahmud, A., Barua, A., Khalil, M. D. I., Chowdhury, R., Ahamed, F., \& Dhar, K. (2016). Bacterial contamination on hand touch surfaces of public buses in Chittagong city, Bangladesh. J Environ Sci Toxicol Food Technol, 10(4): 48-55.

European Committee on Antimicrobial Sensitivity

Testing. (2018, January 01). The updated EUCAST breakpoint table. https://eucast.org/eucast news/news single view/?tx ttnews $\% 5 \mathrm{Btt}$ news $\% 5 \mathrm{D}=28 \mathrm{\& cHa}$

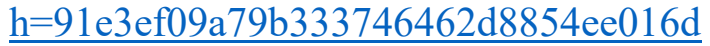

Fluckey, W. M., Loneragan, G. H., Warner, R., \& Brashears, M. M. (2007). Antimicrobial drug resistance of Salmonella and Escherichia coli isolates from cattle feces, hides, and carcasses. Journal of Food Protection, 70(3): 551-556.

Hsu, T., Joice, R., Vallarino, J., Abu-Ali, G., Hartmann, E. M., Shafquat, A., \& Morgan, X. C. (2016). Urban transit system microbial communities differ by surface type and interaction with humans and the environment. Msystems, 1(3): e00018-16.

Kassem, I. I., Sigler, V., \& Esseili, M. A. (2007). Public computer surfaces are reservoirs for methicillin-resistant staphylococci. The ISME journal, I(3): 265-268.

Lindberg, E., Adlerberth, I., Hesselmar, B., Saalman, R., Strannegård, I. L., Åberg, N., \& Wold, A. E. (2004). High rate of transfer of
Staphylococcus aureus from parental skin to infant gut flora. Journal of Clinical Microbiology, 42(2): 530-534.

Meng, J., \& Doyle, M. P. (2002). Introduction. Microbiological food safety. Microbes and Infection, 4(4): 395-397.

Oranusi, S. U., Dahunsi, S. O., Owoso, O. O., \& Olatile, T. (2013). Microbial profiles of hands, foods, easy contact surfaces and food contact surfaces: A case study of a University Campus. Novus International Journal of Biotechnology \& Bioscience, 2(1): 30-38.

Otter, J. A., \& French, G. L. (2009). Bacterial contamination on touch surfaces in the public transport system and in public areas of a hospital in London. Letters in applied microbiology, 49(6): 803-805.

Pittet, D., Dharan, S., Touveneau, S., Sauvan, V., \& Perneger, T. V. (1999). Bacterial contamination of the hands of hospital staff during routine patient care. Archives of Internal Medicine, 159(8): 821-826.

Ray, B. (2004). Fundamental Food Microbiology. CRC Press.

Sleigh, D. J. \& Timbury, M. C. (1998). Note on Medical Microbiology. ChurchchillLivingstone.

Yeh, P. J., Simon, D. M., Millar, J. A., Alexander, H. F. \& Franklin, D. (2011). A diversity of Antibiotic-resistant Staphylococcus spp. in a Public Transportation System. Osong Public Health and Research Perspectives, 2(3): 202-209.

Wehr, H. M., Frank, J. F., \& American Public Health Association (Eds.) (2004). Standard methods for the examination of dairy products (pp. 327-404). American Public Health Association.

Winfield, M. D., \& Groisman, E. A. (2003). Role of nonhost environments in the lifestyles of Salmonella and Escherichia coli. Applied Environmental Microbiology, 69(7): 36873694. 